\title{
USE OF COMPARATIVE SYMBOLS BASED ON DATA TYPE TO FORMULATE A QUESTIONNAIRE
}

\author{
Mochammad Faizal ${ }^{1 *}$, Mochammad Rizky Hidayatullah², Aulia Kharisma Putra ${ }^{1}$ \\ 1 Telkom University Bandung 40257, Indonesia, \\ 2Padjadjaran University Sumedang 45363, Indonesia
}

Article history:

Submission 02 June 2020

Revised 12 September 2020

Accepted 04 December 2020

${ }^{*}$ Corresponding author:

E-mail: hai@mf-chan.com

\begin{abstract}
When it comes to using the unit of a number, some researchers cannot distinguish when to use the comparison symbol while designing a questionnaire. This study will discuss how the use of comparative symbols by the type of data in the questionnaire questions through literature studies. It can be concluded that the use of comparison symbols in the questionnaire options cannot be done when the nominal data type is used. The results of this study can be implemented for designing a research instrument that uses a comparison symbol on the question options.
\end{abstract}

Keywords: Comparison symbol, Nominal data, Questionnaire

\section{Introduction}

In higher education, lecturers, students, and even Extension professionals have conducted research activities. Research can use a variety of approaches be it qualitative, quantitative, or mixed-method. Research with a quantitative approach is a type of research that emphasizes a variety of objective phenomena, where the objectivity of research design is maximized by using statistical processing, structured processing, and controlled experiments (Hamdi \& Bahruddin, 2015 , p. 5). There are many methods for collecting data. In the quantitative research approach, the data collection method that is often used by researchers is a questionnaire method.

Questionnaires can be used in various types of research. In many studies, researchers have determined the criteria of research respondents who can fill out the questionnaire, based on the research purpose. For example, to explain the potential impact of an activity, the researchers assign research respondents in the form of adult participants in the activity (Balis et al., 2019). Another example, when assessing motivation and barriers for landowners to adopt best management practices, the researchers will assign respondents in the form of landowners in watersheds (Dewald et al., 2019), and when the knowledge and perceptions of Mississippi residents about the Mississippi State University extension services, the research respondents are Mississippi residents (Settle et al., 2019). By determining research respondents, researchers are expected to obtain various relevant data to the carried out research.

In studies that designate university students as research respondents, there are usually questions about the student's entry year. Because groups of student's entry year use the unit of a number, it is common for researchers to use mathematical comparison 
symbols in the questionnaire options. However, sometimes researchers cannot distinguish when to use the symbol "smaller than" or " larger than" when designing a questionnaire. This will make confusion or misunderstandings, and research respondents will be unable to answer the question. Based on this phenomenon, this study will discuss how the use of comparative symbols by the type of data in the questionnaire questions, and how to ensure that the respondents have the same understanding by the researchers about the research instruments.

\section{Data Type and Comparison Symbol}

When conducting research, several types of data have been identified. In several publications (Jubilee Enterprise, 2018, pp. 1819), four types of data have been described, such as:

1. Nominal data; the data type that used only to classify certain objects. For example, gender data can be represented by numbers where number 1 represents men and number 2 represents women. It cannot be said that men are less than women, or vice versa.

2. Ordinal data; the data type which level is higher than nominal data types because this data type has a relative ranking. For example, the question of assessing the quality of a product can be stated with numbers 1 through 5 , where number 1 means that the quality of the product is bad, while 5 means the quality of the product is good. But, it cannot be said that "bad" times five is "good".

3. Interval data; the data type that not only have levels but can also be quantified and have a fixed interval of magnitude. This data type has no absolute zero. For example, a temperature data of 0 degrees Celsius means that the temperature is 0 degrees Celsius, it does not mean that there is no temperature.

4. Ratio data; the data type that have the highest level compared to other data types. Ratio data type have absolute zero values and allow for multiplication or division operations. For example, the length of poster $A$ is $40 \mathrm{~cm}$ and poster $B$ is $20 \mathrm{~cm}$, it can be said that the length of poster $A$ compared to the length of poster B is two to one.

Bogomolny (2010) explained that some numerical items can be compared. The symbol "<" signifies "less than", and the symbol ">" signifies "greater than". The pointed end with a solitary endpoint points to the smaller of the two expressions. Furthermore, the symbol " $\leq$ " signifies "less than or equal to", while the symbol " $\geq$ " signifies "greater than or equal to".

\section{Result and Discussion}

This time we will discuss the research conducted by Faizal \& Adriyanto (2018), which assigns high school students or high school graduates as research respondents. In that study, a questionnaire was designed with screening questions that ask the respondent's monthly income and the duration of respondents in accessing the internet every day. The questionnaire questions are illustrated in Figure 1 below.

$$
\begin{aligned}
& \text { 1. How much is your income per month? } \\
& <\operatorname{Rp} 1.000 .000 \text {,- } \\
& \operatorname{Rp} 1.000 .000 \text {,- to } \operatorname{Rp} 2.499 .999 \text {,- } \\
& \operatorname{Rp} 2.500 .000 \text {,- to } \operatorname{Rp} 4.999 .999 \text {,- } \\
& \geq \operatorname{Rp} 5.000 .000 \text {,- }
\end{aligned}
$$

\section{How often do you surf the Internet per day?}
Less than 1 hour
$>1$ hour to 3 hours
$>3$ hours to 5 hours
$>5$ hours to 7 hours
More than 7 hours

Figure 1. The first example of screening questions

In Figure 1, answer options on the first question can be seen using the symbols "less than" and "greater than or equal to." In this question, the answer options use the interval 
data type, because the amount of income has a fixed interval of magnitude (Jubilee Enterprise, 2018, pp. 18-19). In the second question of Figure 1, respondents are given five options for the duration of internet surfing per day. The options on this question also indicate the type of interval data, with two options that explicitly mention "less than" and "more than", and three options that use the symbol "greater than". The use of explicit words as a substitute for comparison symbols can be an alternative that will clarify the options of the question itself. The use of comparison symbols in both questions is appropriate, as explained by Bogomolny (2010). After being tested on 100 random respondents, they understood very well what was asked in the questions above.

For the second scenario, we will discuss the research that has been conducted by Faizal et al. (2018), who set university students as the research respondents. In that study, a questionnaire was designed with screening questions that ask when did the respondents start college, and how old the respondents are. The questionnaire questions are illustrated in Figure 2 below.

1. What year did you start college?
$>2013$
2013
2014
2015
2016
2. How old are you?
$17-20$ years old
$21-24$ years old
$25-28$ years old
more than 28 years old

Figure 2. The second example of screening questions

In the first question of Figure 2, the answer choices are presented in the form of nominal data type because they only classify the class of students (Jubilee Enterprise, 2018, pp. 18-19). Nevertheless, Faizal et al. (2018) write it down using the comparison symbol. The answer choices state that the class of 2012 is greater than the class of 2013, meaning that the class of 2012 students has taken more semesters than the class of 2013 students, and so on. This logic is not fully agreed upon by the research respondents who think that 2012 should be smaller than 2013, judging by the numbers written. However, because this question uses nominal data types, both perspectives are incorrect they should be written in explicit writing to avoid misunderstanding. The second question of Figure 2, is the same example as described in Figure 1.

From the scenarios that have been described, it can be seen several examples of good and bad practices for the use of comparative symbols in the questionnaire questions. This article proves what has been explained by Bogomolny (2010) that some numerical items can be compared, except if they are presented in the form of nominal data types which only serve to classify certain objects (Jubilee Enterprise, 2018, pp. 18-19).

\section{Future Implications}

The results of this study can be implemented by other researchers such as lecturers, students, and even Extension professionals when designing a research instrument in the form of a questionnaire that uses a comparison symbol on the question options.

\section{Conclusion}

From this study, it can be concluded that the use of comparison symbols in the questionnaire options can only be done when the type of data used is not in the form of nominal data. The nominal data is a type of data that used to classify certain objects, with mathematical operations cannot be performed, including the use of the symbol "less than", "greater than", "less than or equal to", or "greater than or equal to ". When designing a research questionnaire, the researcher must pay attention to the use of comparative symbols in accordance with the type of data used, to avoid any misconceptions among the 
respondents when they are filling out the questionnaire. Writing options in exact writing is the right step in increasing respondent's understanding when answering the questionnaire.

\section{References}

Balis, L. E., Marshall, C., Malcolm, A., \& Harden, S. M. (2019). Goat Yoga: Preliminary Implications for Health, Agriculture, and 4-H. Journal of Extension, 57 (3). https://www.joe.org/joe/2019june/iw4.php

Bogomolny, A. (2010). Less than, Equal to, Greater Than Symbols.https://www.cut-the-knot.org/arithmetic/Less-Equal-Greater.shtml

Dewald, S. S., Murphrey, T. P., Leggette, H. R., Berthold, A., \& Wagner, K. (2019). Landowner Adoption of Water Quality Best Management Practices: Motivations and Barriers. Journal of Extension, 57 (5). https://joe.org/ioe/2019october/rb4.php
Faizal, M., Abdillah, M. F., Dea Aulia Sari I. M. S., Setiadi, W., Octavia, D., Suhendari, W., \& Soewardikoen, D. W. (2018). Penggunaan Website Portal Berita sebagai Media Informasi untuk Mahasiswa. Jurnal Bahasa Rupa, 2 (1), 34-42. https://doi.org/10.31598/bahasarupa.v2i1.217

Faizal, M., \& Adriyanto, A. R. (2018). Perancangan Ulang Antarmuka Website Sebagai Media Informasi Perguruan Tinggi Universitas Telkom. Serat Rupa Journal of Design, 2(1), 54-66. https://doi.org/10.28932/srid.v2i1.477

Hamdi, A. S., \& Bahruddin, E. (2015). Metode Penelitian Kuantitatif Aplikasi dalam Pendidikan. Deepublish.

Jubilee Enterprise. (2018). SPSS Komplet untuk Mahasiswa. PT Elex Media Komputindo.

Settle, Q., Brubaker, M., Hardman, A., \& Downey, L. (2019). Mississippi Residents' Perceptions of Extension. Journal of Extension, 57(5). https://joe.org/joe/2019october/rb6.php 